\title{
The Purposes of Sharia (Maqasid Al-Shariah) from Contemporary Scientific Research
}

Saad Gomaa Gomaa Zaghloul, Ahmed Ramadan Mohamed Ahmed, Marina Abu Bakar

To Link this Article: http://dx.doi.org/10.6007/IJARBSS/v12-i1/12067

DOI:10.6007/IJARBSS/v12-i1/12067

Received: 08 November 2021, Revised: 13 December 2021, Accepted: 28 December 2021

Published Online: 15 January 2022

In-Text Citation: (Zaghloul et al., 2022)

To Cite this Article: Zaghloul, S. G. G., Ahmed, A. R. M., \& Bakar, M. A. (2022). The Purposes of Sharia (Maqasid Al-Shariah) from Contemporary Scientific Research. International Journal of Academic Research in Business and Social Sciences, 12(1), $629-639$.

\section{Copyright: @ 2022 The Author(s)}

Published by Human Resource Management Academic Research Society (www.hrmars.com)

This article is published under the Creative Commons Attribution (CC BY 4.0) license. Anyone may reproduce, distribute, translate and create derivative works of this article (for both commercial and non0-commercial purposes), subject to full attribution to the original publication and authors. The full terms of this license may be seen

at: http://creativecommons.org/licences/by/4.0/legalcode

Vol. 12, No. 1, 2022, Pg. $629-639$

Full Terms \& Conditions of access and use can be found at http://hrmars.com/index.php/pages/detail/publication-ethics 


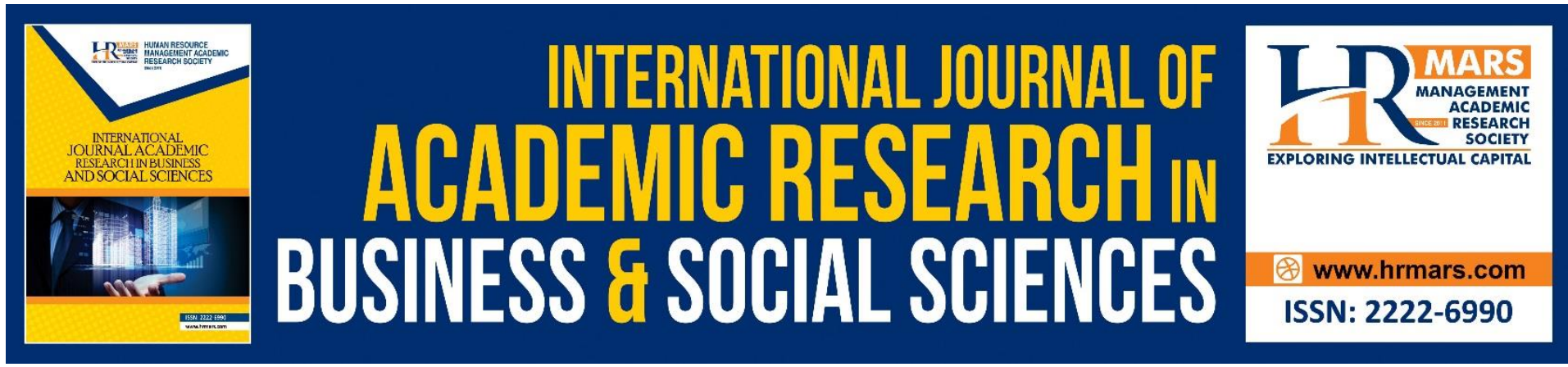

\title{
The Purposes of Sharia (Maqasid Al-Shariah) from Contemporary Scientific Research
}

\author{
Saad Gomaa Gomaa Zaghloul ${ }^{1}$, Ahmed Ramadan Mohamed \\ Ahmed $^{2}$, Marina Abu Bakar ${ }^{3}$ \\ ${ }^{1,2}$ Senior Lecturer, Kulliyyah of Shariah and Law, Universiti Islam Antarabangsa Sultan Abdul \\ Halim Mu'adzam Shah (UniSHAMS), 09300, Kuala Ketil, Kedah, ${ }^{3}$ Lecturer, Kulliyyah of \\ Shariah and Law, Universiti Islam Antarabangsa Sultan Abdul Halim Mu'adzam Shah \\ (UniSHAMS), 09300, Kuala Ketil, Kedah. \\ Corresponding author: saad@unishams.edu.my
}

\begin{abstract}
One of the aims of Sharia is scientific research and exploration. Scientific investigation and zeal for this noble goal have been highlighted by Islamic scholars because it serves the general purposes of Islamic law. The study of Islamic law's aims is considered current scientific research. It is regarded as one of the most important types of research in all branches of science. As it is valid for all times and places, the Sharia got to the end of the celestial rules. From this point of view, the significance of scientific study emerges, as does the declaration of its legitimate aims, which would benefit science and scholars. The aim of this study is to identify the fact of scientific research, to underline the relationship between scientific research and legitimate purposes, and eventually to clarify the Sharia regulations in the context of contemporary scientific research. This study utilized a qualitative approach, collecting data from secondary sources and analysing it using the content analysis method. According to the findings, specific guidelines must be followed to ensure that Sharia's goals are met in contemporary scientific research. This research is beneficial to Islamic researchers, particularly in terms of retaining the aims of Sharia in their contemporary scientific research.
\end{abstract}

\section{Introduction}

Praise be to God, Lord of the Universe, and prayers and peace be upon the most honourable of the prophets and messengers, our master Muhammad, and upon his family and companions, and may the peace and blessings be abundantly. Scientific research and exploration for science is one of the purposes of Islamic Sharia. It is well known that reading is the first key to scientific research that Islam seeks from scholars and students. Allah says:

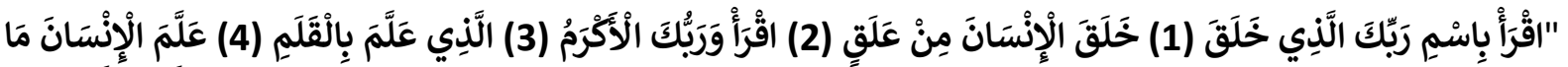

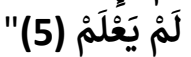

(al-'Alaq: $1 / 5$ ) 
Recite in the name of your Lord Who created (1) created man from a clot of congealed blood (2). Recite: and your Lord is Most Generous (3) Who taught by the pen, (4) taught man what he did not know (5).

Then the surahs and Quranic verses that call for seeking knowledge, research and exploration for knowledge and serving humanity followed. Then came Surat Al-Qalam, which is one of the tools of research and science, and the surah opened with the oath with the pen and letters. Allah says in Surah al-Qalam, verse 1, which means: "Nun. By the pen and what the scribes write". The one who looks at the Holy Quran will find many verses that include legal commands between the obligation and the recommendation to seek knowledge and scientific research. Allah says in Surah al-Tawbah, verse 122, which means: "It was not necessary for the believers to go forth all together (to receive religious instruction), but why did not a party of them go forth that they may grow in religious understanding, and that they may warn their people when they return to them, so that they may avoid (erroneous attitudes)?" And if we turn to the Sunnah and hadiths of the Prophet, peace be upon him, we find that there are many hadiths and texts that call for science and scientific research. We will mention some of them in the folds of the research in the coming pages, which confirms the importance of the purpose of scientific research in Islamic law, as the Prophet stipulated the hypothesis of seeking knowledge for every Muslim as stated in the hadith brought out by the authors of the Sunan: "Seeking knowledge is an obligation upon every Muslim".

Islamic scholars have emphasized the importance of scientific research and keenness on this noble goal, because by it the general purposes of Islamic law are achieved. Al-Hafiz Al-Suyuti mentioned in the introduction to his book Al-Itqan fi 'Ulum al-Quran, the importance of research and study in the sciences and the purpose of scientific research:

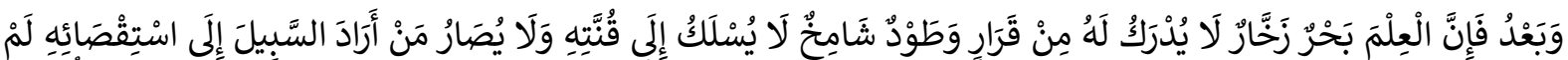

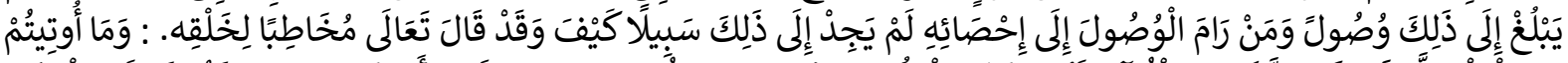

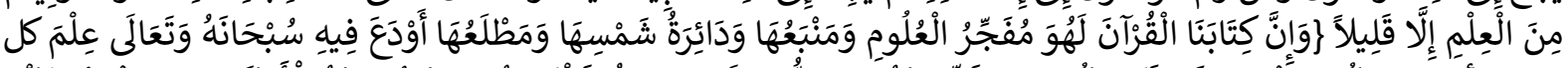

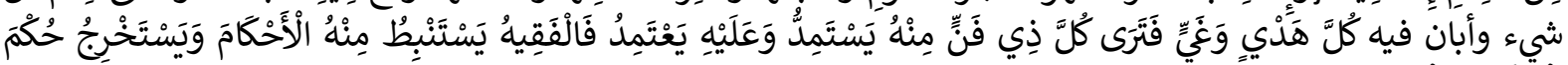
الْحَلَالِلِ وَالْحَرَاْمِم.

The grammarian builds from it the rules of its syntax and returns to it in recognition of the error of the correct statement. The rhetoric guides him to good order and considers the paths of rhetoric in formulating speech. "The stories and news mention initial sight and sermons and parables what scholars' thought. No estimates of only aware of this confined with the eloquence of the word and eloquence style fascinates minds and hearts and rob miracles of systems only an unseen". For the sciences, even if they are numerous and spread among the submissive, their extensions, and their end is an ocean whose bottom is not comprehended. And its end is a lofty mound, it is not possible for it to reach its peak, and this opens to another world beyond the gates that they have not been able to enter.

\section{The Importance of Study}

The study of the purposes of Islamic law is considered contemporary scientific research. It is one of the most important studies in the field of science of all kinds and fields. The Islamic Sharia came to the conclusion of the heavenly laws, as it is valid for every time and place. 
From this standpoint, the importance of scientific research appears, and the statement of its legitimate purposes that would serve science and scholars.

\section{Study Questions}

Through this research paper, we try to answer the following questions:

What is meant by scientific research?

What are the purposes of scientific research in Islamic law?

What are the regulations for scientific research?

What are the objectives of Islamic law of scientific research?

\section{Objectives of the Study}

The study aims to achieve some goals, including:

- Statement of the fact of scientific research

- Emphasis on the relationship of scientific research with legitimate purposes

- Explanation of Sharia regulations in the purpose of contemporary scientific research

\section{Research Plan}

This research paper is divided into an introduction, three chapters, and a conclusion. Introduction: It included the importance of the topic, the reasons for choosing it, the approach followed, and the objectives of the study. Introductory study: definition of search terms. The first topic: the purposes of research and writing. The second topic: the objectives of Sharia in scientific research. The purpose of scientific research and preservation of the five Sharia colleges.

\section{Definition of Research Terms}

\section{First: Defining the Purposes in the Language}

The word "maqasid" from the triple verb "qaf sad dal" means intent. The derivatives verb (Masdar mimi) is maqsadan. The plural word is maqasid. It has several definitions for Arab uses, including: The first: the intention, dependence, and request for something came in the luminous lamp (I meant something for it and for it on purpose, by way of hitting: I asked for it specifically). The second: righteousness, and from it is the saying of the Most High: (And upon God is the purpose of the way) An-Nahl, verse 9. The third: justice and mediation between two parties, and from it is the Almighty's saying: "And among them is he who is thrifty, and among them is the forerunner of good deeds." Fatir 32.

\section{Second: Defining the Objectives Idiomatically}

Imam Abu Hamid Al-Ghazali defined it by saying: "Maslahah is an expression of bringing benefit or repelling harm". Al-Amidi defined it with a definition that was not far from the definition of Imam Al-Ghazali, where he said: (The meaning of the law of governance: either to bring benefit or repel harm, or the combination of the two things). Al-Shatibi defined it as: Establishing the interests of the world and the hereafter, as he says in al-muwafaqaat (that the legislator intended by legislation to establish the interests of the world and the hereafter).

Ibn Ashour defined it from his contemporaries by saying: (The notable meanings and rulings of the Lawgiver in all or most cases of legislation, so that their observation is not limited to the universe in a special type of Sharia rulings. This includes the descriptions of the Sharia, its 
purpose, and the meanings that the Sharia does not fail to observe. This also includes meanings of the ruling that are not noticeable in other types of rulings, but are noticeable in many of them. Al-Raysuni defined it by saying: "They are the goals that the Sharia was established in order to achieve them, for the benefit of the people."

\section{Definition of Sharia}

First: Sharia in language: It is a source of Sharia, and it has two meanings: -

The straight path, and the word of God Almighty:

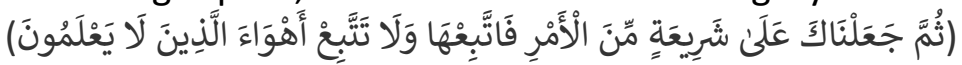

That is, we made you a straight path. The source of running water that is intended for drinking, it is said: The camel is legal if it intends to drink water. Second: Sharia in terminology: What God Almighty has legislated for His servants from the rulings that were brought by one of the prophets, peace and blessings be upon them, whether these rulings were provisions of belief or practical rulings for them to believe in, so that their happiness would be in this world and the hereafter. By adding the word Islam to the Sharia, the meaning of Islamic Sharia becomes: the rulings that were revealed to Muhammad, may God's prayers and peace be upon him, from the rulings that fix people's conditions in this world and the next, whether they are doctrinal rulings, practical rulings, or morals.

The Purposes of Research and Authorship and Its Impact on Achieving Legitimate Interests The first requirement: the relationship between the purposes of contemporary research and the achievement of the faculties of Sharia

Before delving into the purposes of contemporary research and authorship, we would like to take a look at the relationship of scientific research with the five Sharia faculties that were decided by Islamic Sharia and ordered to preserve them, and through which the importance of scientific research in maintaining these respected Sharia faculties can be realized. Hujjat alIslam al-Ghazali expressed these legal faculties by saying: "Preserving the intent of the Sharia. The purpose of Sharia is five things, which is to preserve for them their religion, their soul, their mind, their offspring and their money. Everything that includes preserving these five principles is an interest." The interest is divided into three types: considered, void, and sent. Considered interest: it is the one that the legislator has indicated to consider, and it is divided into three categories as well, al-Daruriyyat (basic needs and necessities), al-Hajiyyat (additional needs) and al-Tahsiniyyat (perfection). Necessary interests: which are necessary for the establishment of religion and this world, so that if they were lost, the interests of this world would not be kept upright, and the sum of these necessities are five: "Preservation of religion, self, offspring, money and reason." Needful interests: They are what is lacking in terms of expansion and relief of distress, which often leads to difficulty and hardship. But it does not reach the normal amount of corruption expected in public interests, and it is ongoing in worship and customs, transactions and crimes. Ameliorative interests: It is the adoption of what befits the virtues of customs, and avoiding the degrading conditions that the preponderant minds rebuke, and this combines with noble morals.

Void interests: These are interests for which the Sharia evidence is based on their nullification, and the lack of consideration for them. Because it may be tainted with some evil. Therefore, the legislator abolished it, namely put in place some rulings that indicate its neglect, such as exaggeration in religious monasticism, and the interest of the coward not to fight the battle, and so on. 
Sent interests: They are the interests for which there is no specific Sharia evidence as being or canceling them, except that they are consistent with the purposes and general objectives of the Sharia. The interest sent is a medium between two parties. An interest that is restricted in the Sharia by consideration, and an interest that is nullified due to its opposition to a text in the Sharia. The Companions acted with interest in many issues, they worked in matters of absolute interest, not to provide a witness with consideration.

\section{The Second Requirement: The Purposes of Contemporary Scientific Research}

In order to achieve the desired benefit from scientific research, the researcher must set in mind a specific goal of his study, seeking from behind the study to achieve that goal. Through research and induction, we can define in general the purposes and goals that the researcher should strive to achieve through research and study, and in their entirety, they do not depart from one of the following:

First: Striving to Achieve new Knowledge in it in Addition to Science, Meaning either there will be new Developments. It is very important as it has a direct link to people's lives, whether in their livelihood or in their religion, and people need to know the opinion of the street in this calamity. This was summed up by Imam Abu Bakr bin al-Arabi al-Maliki in his commentary on al-Tirmidhi in general, by saying: (It is not necessary for a prudent person to address a classification to deviate from two purposes: either he invents a meaning, or he invents a situation and text, and other than these two aspects, it is blackening the paper, and the decoration of theft.

Second: Correcting a scientific error: or that there is a common and inherited error that needs to be corrected. Raising awareness of the people and drawing their attention to this hereditary mistake. Ibn Khaldun referred to this intent and said what he said: That the latecomer finds a mistake or a mistake in the words of the forerunners of those whose virtues are well known and whose reputation is far from the statement. He trusts in this clear evidence that has no room for doubt, so he is keen to communicate that to those after him, as it has been impossible to erase and remove it with the spread of authorship in horizons and hurricanes. The author's fame and the people's trust in his knowledge, so this book is deposited to stand on the clarification of that.

Third: Removing the ambiguity of a subject: or a subject that is still ambiguous or difficult to understand and has not taken its due from study, explanation and clarification. With regard to this purpose, Ibn Khaldun says: If he stands on the words of the ancients and their writings, he finds them closed to understanding. And God opens it to him in understanding it, so he is keen to make this clear to others who may be closed to him, so that the interest reaches the one who deserves it. This is the method of explanation for the books of Reasonable and Manufactured, and it is an honorable chapter.

Fourth: Proving a new hypothesis that is beneficial to scientific progress. Through it, the researcher tries to research and complete induction in order to reach the ratifications of this new hypothesis.

Fifth: Resolving an emerging problem. You need to find solutions for it. And that is through research and study, and perhaps most of the contemporary applied sciences stem from this 
matter, which is an attempt to treat contemporary problems, whether they are social, economic, medical, or other problems in multiple fields.

\section{The Status of Scientific Research and The Objectives of Islamic Law From it The first requirement: the status of scientific research in Islam}

Islamic law has given special attention to scientific research, and Islam has taken care of science, research and induction. Whoever peruses the texts of the Noble Qur'an and the purified Sunnah of the Prophet will find that it is full of verses and hadiths that call for research and knowledge. Rather, the belief of a Muslim must be based on research and complete induction so that the belief is correct based on certainty. Whoever peruses the Noble Quran will find that the first Surah revealed to the Messenger of God, may God bless him and grant him peace, enjoins reading and learning. Allah Almighty said: Recite in the name of your Lord Who created (1) created man from a clot of congealed blood (2). Recite: and your Lord is Most Generous (3) Who taught by the pen, (4) taught man what he did not know (5). (al-Alaq: 1-5). Imam Al-Alusi says in the interpretation of these noble verses: "And the Glorified and Exalted has included the warning on the virtue of the science of writing because of the great benefits it contains and the attainment of high ranks. Without it, no religion would be established and no livelihood would be correct, and if it was not based on the precise wisdom of God Almighty and the gentleness of His management, Glory be to Him, evidence except the command of the pen and calligraphy, it would suffice with it". From these verses it becomes clear to us as the commentators have decided the importance of reading in achieving the purposes of Islamic Sharia. That is why the Prophet, peace and blessings be upon him, made the sacrifice of a captive of the infidels of Quraysh in the Battle of Badr, teaching ten Muslim children to read and write. The Holy Quran calls for contemplation of the universe and of God Almighty's creatures in more than one place, and this contemplation is the first degree of scientific research. Allah Almighty said, which means: "Surely in the creation of the heavens and the earth, and in the alternation of night and day, there are signs for men of understanding. those who remember Allah while standing, sitting or (reclining) on their backs, and reflect in the creation of the heavens and the earth, (saying): 'Our Lord! You have not created this in vain. Glory to You! Save us, then, from the chastisement of the Fire" (al-Imran: 190-191)

The Prophet, peace and blessings be upon him, called for seeking knowledge, research, and pursuing beneficial knowledge that serves Islam and Muslims. Al-Hafiz Ibn Abd al-Bar narrated his book, Jami al-Bayan al-Ilm and its Excellence, on the authority of: "Jaber said: The Messenger of God, peace and blessings of God be upon him, said that among the minerals of piety it teaches you to what you have learned, knowledge of what you did not know, and the deficiency in what you knew is a lack of increase in it, benefit from what he knows". And the Prophet, peace and blessings be upon him, made seeking knowledge a duty upon the Muslim, as he, peace be upon him, said: "Seeking knowledge is a duty upon every Muslim". Even the previous prophets sought knowledge, so this prophet of God Moses (peace be upon him) strives to seek knowledge as the Holy Quran mentioned to us that, the Almighty said, which means: "and there they found one of Our servants upon whom We had bestowed Our mercy, and to whom We had imparted a special knowledge from Ourselves. Moses said to him: "May I follow you that you may teach me something of the wisdom which you have been taught? He answered: "You will surely not be able to bear with me. For how can you patiently bear with something you cannot encompass in your knowledge? Moses replied: "You shall find me, if Allah wills, patient; and I shall not disobey you in anything". He said: "Well, if you follow me, 
do not ask me concerning anything until I myself mention it to you"(al-Kahf: 65-70). In these noble verses, the Noble Qur'an shows how the Prophet of God Moses (peace be upon him) asked to accompany Al-Khidr for learning. Al-Fakhr Al-Razi mentioned the specification of knowledge to rationality in his interpretation of the verses as follows: "The Almighty said: \{Moses said to him: "Shall I follow you on the basis that you teach from what you have taught guidance"?

Second: It means that you teach me what you have learned so that God will guide you. Third: What he sees in the science of al-Khidr that he does right and wrong that he avoids, so Moses asked him to teach him about the rightness that he does. And he did not ask him to teach him the transgression that he avoids, because he knew the transgression that he avoids, and he did not know that rationality.

\section{The second requirement: the objectives of Islamic law from contemporary scientific research}

The one who examines the texts of Islamic Sharia with a complete extrapolation of these texts will find that Islamic Sharia has set a set of goals from the purpose of contemporary scientific research. These goals would achieve progress and development for the Muslim community in particular and for the human community in general.

First: Reaching the abstract or objective truth in arriving at judgment without being influenced by whims or fanaticism, taking the principle laid down by the Messenger of God, peace and blessings be upon him, which is to refer first to the Qur'an, then the Sunnah, and then to ijtihad for those who fulfil the conditions of ijtihad. This is reflected in the following:-

In the authentic hadith on the authority of Ibn Abbas, may God be pleased with them both, that the Prophet, may God bless him and grant him peace, sent Muadh, may God be pleased with him, to Yemen, and he said, "Invite them to testify that there is no god but God and that I am the Messenger of God, for they will obey." Therefore, teach them that God has enjoined upon them five prayers every day and night, so if they obey. Therefore, teach them that God has enjoined upon them a charity in their money to be taken from the rich and given back to the poor. (Muttafaqun 'alaih)

It also appears clear in the story of Tohma bin Abiraq - the apparently Muslim - when the Jew was accused of stealing the armor of Qatada bin Numan. This story was narrated by the Quran in the Almighty's saying, which means: "And do not argue on behalf of those who deceive themselves. "Indeed, Allah does not love the one who is treacherous and sinful." (al-Nisa: 107). The Prophet, may God's prayers and peace be upon him, was his rib with the Muslim, since the apparent evidence points to accusing the Jew on the grounds that the shield was found with him in his house, so the noble verse was revealed. So, God refused, except for the whole truth to be revealed without favoritism for the Muslim, despite the fact that there is no embarrassment in this matter for the Muslims.

\section{Second: Verify the Carrier of the Information}

This is clearly shown in Surah al-Hujurat verse 6, which means: "Believers, when an ungodly person brings to you a piece of news, carefully ascertain its truth, lest you should hurt a people unwittingly and thereafter repent at what you did". The Messenger of God sent Al-Waleed 
bin Uqbah to Al-Harith to collect what he had from the zakat he had collected. When AlWaleed walked until he reached some of the road, he separated and returned. So, he came to the Messenger of God and said: Al-Harith withheld the zakat from me and wanted to kill me. So, the Messenger of God struck resurrection to Al-Harith, so Al-Harith came with his companions until met him and he was separated from Medina. They said: This is Al-Harith. When he covered them, he said: To where? They said: To you. He said: Why? They said: The Prophet, may God bless him and grant him peace, sent you Al-Waleed bin Uqbah. He claimed that you prevented him from paying zakat and wanted to kill him. He said: No, by the One who sent Muhammad with the truth, I did not see it, nor did he come to me. When Al-Harith entered the Prophet, he said: I withheld the zakat and wanted to kill my messenger?! He said: No, by the One who sent you with the truth, I did not see it, nor did he come to me. I only came when the Messenger of God, may God's prayers and peace be upon him, seized me; I feared that she was discontented with God and His Messenger. So, the verse was revealed.

It should also be made clear that verification should not be limited to immorality only; "O you who have believed, if a wicked person comes to you with news, investigate..." Because some of the righteous think well of people and believe their words, and then pass them on to those around them, so he crossed the letter (inna) that is useful for doubt to notice that the believer is most likely to be vigilant. His mind judges what he hears of news, and that is why we deny the term (news) to benefit the general public, so it includes any news.

Third: Refer to the specialists: This can be seen clearly in the verse:

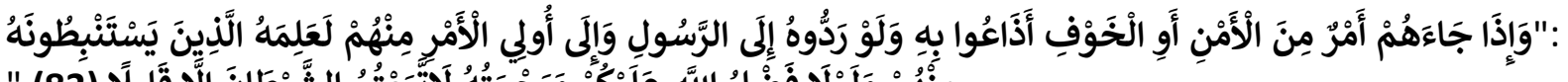

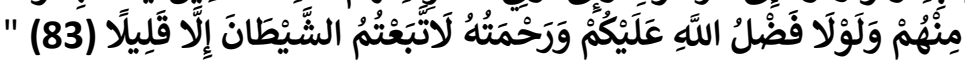

The meaning is that if they hear something about it, they are safe towards the victory of the Muslims and the killing of their enemy (or fear), and it is against this (they publicize it), namely they disclose it, make it public, and speak about it before they stand on its truth. It was said: This was from the weakness of the Muslims, on the authority of Al-Hassan, because they were revealing the order of the Prophet, may God bless him and grant him peace, and think that they had nothing to do with that. Ad-Dahhak and Ibn Zayd said: He is among the hypocrites, but they forbade that, because of the lying that they afflicted with trembling. The Almighty said: (And if they refer it to the Messenger and to those in authority among them) meaning, they did not narrate it and did not divulge it until the Prophet, may God bless him and grant him peace, is the one who narrates it and discloses it. Or those in authority who are the people of knowledge and jurisprudence, on the authority of Al-Hasan and Qatadah and others. AsSuddi and Ibn Zayd: the rulers. It was said: The princes of the Saraya (for his knowledge of those who derive it from them), namely they extract it, namely to know what should be disclosed from it and what should be concealed.

In this regard, Imam Ibn Kathir says: His saying - the Most High - and when a matter of security or fear comes to them, they spread its denunciation to those who hasten to matters before they are realized, informs them, discloses them, and publishes them, and it may not be true. It was narrated that Imam al-Shafi'i said to Ahmad bin Hanbal when he met him on the second journey to Baghdad in the year one hundred and ninety - and Omar Ahmad at that time was thirty-plus years old - he said to him: O Abu Abdullah, if the hadith is true with you, let me know about it, Iraqi or Yemeni. I mean, he does not say, according to the sayings of the jurists 
of the Hijaz, who only accept the narration of the Hijazi's and bring down hadiths from other than them, the status of the hadiths of the People of the Book. Al-Shafi'i's saying of this article is veneration for Ahmad, and veneration for him, and that he has this rank, and if it is correct or weak, he returns to it. It also indicates his recognition of Imam Ahmad as a leader in the field of hadith, and this is not wrong and does not detract from the position of Imam al-Shafi' $i$ as a teacher of Ahmad ibn Hanbal, may God be pleased with them both.

Fourth: Checking the truth of the information and making sure that it is correct. The Quran told us the story of Prophet Solomon, peace be upon him, when the hoopoe came to him with the news of Bilqis and her people. Allah Almighty says, which means: "Not before long the hoopoe came up and said: "I have obtained a knowledge which you could not. I have brought for you sure news about Sheba. I found there a woman ruling over them, one who has been endowed with all things and has a mighty throne. I found that she and her people prostrate themselves before the sun rather than Allah. "Satan has made their deeds appear attractive to them and has, thus, debarred them from the Right Path so they do not find true guidance" (al-Naml: 22-23)

So, what did Solomon, peace be upon him, do? Did he accept the news from the hoopoe without confirming it, or did he reject it just because what he brought was a weak bird, neither this nor that, but rather he worked to verify the information? He sent her a letter of inquiry to confirm the truthfulness of the information transmitted to him by the hoopoe, and this is what the Quran narrated in the Almighty's saying. "Take this letter of mine, deliver it to them, and then draw back from them, and observe what they do". (al-Naml: 28). In Sahih Muslim, on the authority of Abu Hurayrah, on the authority of the Messenger of God, may God's prayers and peace be upon him, that he said: "It is sufficient for a person to narrate everything that he hears. Claims and lack of certainty are forbidden. Rather, it is necessary to verify and confirm the information. It came in the Sunan of Abu Dawud that the Messenger of God, peace and blessings be upon him, said: (Evil is the ride of the man they claimed).

\section{Fifth: Not to Belittle Someone of Lesser Rank}

In the story of the Prophet Solomon, peace be upon him, with the hoopoe, there is evidence for that. Allah Almighty said, which means: "Solomon said: "Soon shall we see whether you have spoken the truth or are one of those that lie". And in the verse, there is evidence that the young man says to the old and the educated to the world: I have what you do not have, if that is achieved and is certain. This is Omar Ibn Al-Khattab with His Majesty, may God be pleased with him, and his knowledge was not known to him for permission. The knowledge of tayammum was with Ammar and others, and he was absent from Umar and Ibn Mas'ud until they said: Do not perform tayammum in a state of impurity. The ruling on permission was for a menstruating woman to be alienated by Ibn Abbas, and neither Omar nor Zaid bin Thabit knew of him. Washing the head of Muharram was known to Ibn Abbas and was hidden from Al-Miswar bin Makhrama. And it is very similar to that.

Fifth: Humility in seeking knowledge, searching for information, and not being condescending to others, while being patient when receiving. This was evident in the companionship of the Prophet of God, Moses, peace be upon him, to al-Khidr in his quest for knowledge from al-Khidr. Allah says, which means: "Moses said to him: "May I follow you that you may teach me something of the wisdom which you have been taught?". He answered: 
"You will surely not be able to bear with me. For how can you patiently bear with something you cannot encompass in your knowledge? Moses replied: "You shall find me, if Allah wills, patient; and I shall not disobey you in anything. He said: "Well, if you follow me, do not ask me concerning anything until I myself mention it to you". (al-Kahf: 66-70). Al-Qurtubi says: "It has two questions]: The first is the Almighty's saying: "Moses said to him: Shall I follow you?" This is a question of politeness, and the uttered one who exaggerates in good manners. This is as in the hadith: Can you show me how the Messenger of God, may God's prayers and peace be upon him, used to perform ablution? On some interpretations, the Almighty says: "can your Lord send down to us a table [spread with food] from the heaven? (al-Maidah: 112)

\section{References}

Ibn Abdul Barr. (2003). Jami' Bayan al-'ilm wa fahdlih. Dar Ibn Hazm, Cairo.

Ibn Manzur, (undated)Lisanu al-Arab. Dar Sader, Beirut, Lebanon $\geq$

Ibn 'Asyur, Muhammad al-Tahir, Maqasid al-Shari'ah.(2005). The edition of the Qatari Ministry of Awqaf $1425 \mathrm{AH}$.

Al-Amidi, A. bin M., Al-ahkam, Al-A. Fi. U. (undated). The Islamic Office Second Edition 1402 $\mathrm{AH}$

Al-Fakhr, Al-R., Mafatih, Al-Ghaib. (undated). Dar Al-Fikr, Beirut, Lebanon

Al-Ghazali, Hujjatu al-Islam, al-Mustasfa. Al-Mustafa, Al-Resala Foundation, Beirut, Lebanon, first edition, (1997)

Al-Raysuni, A., al-Fikri al-Maqasid qawaiduhu wafawaiduhu. (1999) Dar Al-Najah, Casablanca, Morocco,

Al-Suyuti, Al-Itqan fi ulumi al-Quran. (2009) Al-Resala Foundation, Beirut, Lebanon

Al-Syatibi, Abu Ishak Ibrahim, al-Murafaqat. undated House of Knowledge, Beirut, Lebanon, Al-Qarafi, al-Furuq (1998). Scientific Books House, Beirut, Lebanon.

Madkur, M. S., Al-ljtihad, M. (1973). Kuwait University Publications, 